\title{
Omega 3 Fatty Acids Effect on the Vascular Calcification Biomarkers Fetuin A and Osteoprotegerin in Hemodialysis Patients.
}

Rehab H. Werida ( $\sim$ rehabwrieda@pharm.dmu.edu.eg )

Damanhour University Faculty of Pharmacy https://orcid.org/0000-0002-5983-3993

\section{Sohaila Abou-Madawy}

Damanhour University Faculty of Pharmacy

\section{Mohamed Abdelsalam}

Alexandria University Faculty of Medicine

\section{Maged Helmy}

Damanhour University Faculty of Pharmacy

\section{Research Article}

Keywords: Fetuin-A, Osteoprotegerin (OPG), Omega-3 Fatty Acids, CRF, Hemodialysis, Vascular Calcification.

Posted Date: June 21st, 2021

DOl: https://doi.org/10.21203/rs.3.rs-392860/v1

License: (c) (i) This work is licensed under a Creative Commons Attribution 4.0 International License. Read Full License

Version of Record: A version of this preprint was published at Clinical and Experimental Medicine on July 20th, 2021. See the published version at https://doi.org/10.1007/s10238-021-00740-w. 


\section{Abstract}

Chronic Renal failure patients on dialysis are at a high risk of death due to vascular calcification (VC). This study aimed at investigating the effect of omega3- fatty acids on the vascular calcification biomarkers fetuin-A and Osteoprotegerin (OPG) in patients with chronic renal failure (CRF) who are undergoing hemodialysis. This prospective, open-label, controlled, parallel study included 60 hemodialysis patients who were randomized to receive either omega-3 fatty acids capsule along with their standard care of treatment (omega-3 group) or their standard care of treatment only (control group). Serum levels of fetuin-A, OPG, calcium, phosphorus, hemoglobin, parathyroid hormone (PTH), blood urea nitrogen (BUN), albumin (ALB), serum creatinine ( $\mathrm{SCr}$ ), and serum triglycerides (TG) were measured at baseline and after six months of intervention and follow-up of both groups. Significantly increased levels of fetuin-A and OPG $(\mathrm{p}<0.001)$ were observed in the omega-3 group six months after the intervention compared with the control group. Levels of calcium, phosphorous, hemoglobin, parathyroid hormone, BUN, albumin, SCr, and TG were not significantly changed in the omega-3 group or the control group after six months of intervention. Our study concluded that omega-3 may have a clinically beneficial effect in decreasing cardiovascular events by increasing the levels of the protective vascular calcification inhibitors fetuin-A and osteoprotegerin in chronic renal failure patients who are undergoing hemodialysis.

\section{Introduction}

Cardiovascular disease (CVD) is known to be a major cause of death in chronic renal failure (CRF) patients who are undergoing hemodialysis (HD) [1].The most contributing factor is the large arteries damage due to the occlusion or the stiffening that occurs as a result of increased calcium content and/or widespread calcification [2]. In vitro studies showed that vascular calcification (VC) mainly occurs in vascular smooth muscle cells (VSMCs) which are the main constituents in the medial arterial layer [3]. VC is a passive process due to the increased serum levels of phosphate and calcium phosphate products that leads to plasma oversaturation [4]. In uremic patients, a decline in the normal calcification inhibitors levels, fetuin-A, and $O P G$, linked to an increase in the calcium-phosphate deposition in the extra-skeletal tissues [5].

Fetuin-A is a homologues glycoprotein produced in the human liver, then secreted in the blood stream [6]. A pervious animal study conducted on mice with fetuin-A knockout illustrated that fetuin-A is a potent inhibitor of ectopic calcification [7] because it plays an important role in the inhibition of calcium phosphate deposition in smooth tissues [8]. Long-term HD patients showed lower levels of fetuin-A when compared with the healthy individuals [9].

OPG is glycoprotein that expressed in many body tissues, such as blood vessels, bones [10] and VSMCs [11]. OPG is a member of the tumor necrosis factor (TNF) receptor family, binds to the ligand for receptor activator of nuclear factor kappa $B$ and inhibits bone loss and resorption [12]. It has been reported that OPG inhibits plaque progression by preventing lesion and calcification of blood vessels [13]. 
Over the past few years, a various research demonstrated the efficacy of omega 3 supplementation in treating various diseases as adding omega- 3 to simvastatin with dietary modifications improved nonHDL-C and other lipid and lipoprotein parameters more than using simvastatin alone in patients with elevated serum triglyceride (TG) [14]. Omega 3 have a synergistic cardio-protection when added to metformin by improving myocardial ultrastructure and its autophagic activity [15]. Other studies reported that high dose omega-3 fatty acid administration ameliorates acute and chronic vascular inflammation and may lower the incidence of heart failure $[16,17]$, slows down the progression of atherosclerosis [18] and might have anti-inflammatory effects against CVD in HD patients [19]. Recent study suggested that omega-3 fatty acids, a group of polyunsaturated fatty acids (PUFAs), have a positive effect in the treatment of different renal diseases such as diabetic nephropathy and cyclosporine nephrotoxicity [20]. In patients with NAFLD, studies showed that omega-3 may help in decrease liver fat, improving fatty liver and may also improve blood lipid levels and obesity [21]. Moreover, eicosapentaenoic acid (EPA) supplementation enhanced the cognitive function and was superior to docosahexaenoic acid (DHA) [22].

From this prospective especially there is no study investigated the impact of oral omega 3 supplementation on vascular calcification biomarkers Fetuin A and Osteoprotegerin in hemodialysis patients. Our study aimed at evaluating the effect of omega-3 supplementation on the calcification inhibitors' biomarkers fetuin-A and OPG in HD patients.

\section{Patients And Methods}

\subsection{Design}

A randomized controlled, open-label, parallel study enrolled 60 female patients with CRF on hemodialysis, from Nephrology Unit at Al Mouwasat University Hospital between January 2019 and May 2020. Patients on HD were randomized by a computer-generated randomization list in a 2:1 ratio to receive either omega-3 fatty acids ( $1 \mathrm{~g} /$ day) with their standard care of hemodialysis treatment for six months in the omega-3 group or their standard care of treatment only in the control group. Patients were managed according to an institutional protocol based on the Good Clinical Practice Guidelines and Standard Protocol Items: all patients received standard of care dialysis at their usual satellite dialysis units during the conduct of this study [23]. This study was approved by the Faculty of Pharmacy-Damanhour University Ethical Committee (No: 418PP6) and registered on clinicaltrial.gov under identifier NCT03982966. All participants signed informed forms the before biggening of the study.

\subsection{Patients}

Out of 109 dialysis patients who were screened for their eligibility, 63 patients were enrolled in the study. The inclusion criteria included 25 to 75 years old female patients with CRF on HD performed three times per week for at least six months prior enrollment to the study. Patients with active infections, known malignancy, connective tissue disorders, inflammatory diseases, or recurrent bleeding were excluded. In addition, those have been recently undergoing dialysis for less than six months, male patients, currently using warfarin or taking anticonvulsants, glucocorticoids, or immunosuppressant drugs were excluded. 
During the study period, all participants were asked to maintain their regular medications and follow their regular diet and level of physical activity. The patients were interviewed three times weekly during their routine HD sessions to encourage adherence to the recommended supplement regimens, and to recognize the tolerance and the possible side effects of the trial supplementation. Any changes in their medications, and patient complaints were recorded throughout the study. Pill count was used to monitor the participants adherence and was calculated as the number of pills taken by subtracting the number of pills left in the bottle during a patient scheduled refill from the number of pills given. The number of pills participants were expected to have taken was calculated by multiplying the daily dose by the number of days since the date of pills dispensed. The number of pills taken was then divided by the total number of pills at the beginning, which was then multiplied by 100 to get the percent of pill count adherence [24]. We defined successful adherence on pill count as $95-100 \%$ of pills taken during follow-up appointment and less than $95 \%$ of medication taken considered to be poor adherence. Those with poor adherence were excluded from the study. Body Mass Index (BMI) was calculated using the following equation [25]: $\mathrm{BMI}=$ Weight (in kilograms)/squared height (in meters).

\subsection{Blood Samples and Laboratory Evaluation}

Blood samples were drawn before the dialysis session then centrifuged and stored at $-80^{\circ} \mathrm{C}$ until the analysis at baseline and after six months of intervention. Fetuin-A and OPG were assessed by the enzyme-linked immunosorbent assay (ELISA) kit (Sunred Biological Technology, Shanghai, China), according to the manufacturer's directions. Triglycerides, albumin, serum creatinine, BUN, phosphorus, calcium, hemoglobin, and PTH levels were measured using the enzymatic colorimetric method.

\subsection{Statistical Analysis}

Analysis was performed using SPSS software statistical computer package version 25.0 (SPSS Inc, Chicago, IL, USA). Kolmogorov-Smirnov, and Shapiro-Wilk normality tests were used to assess Normality of the studied parameters. Variables that do not follow normal distribution are expressed as median (range) and were analysed using Wilcoxon signed ranks test to compare before and after the intervention and Mann-Whitney test to compare between both groups. Continuous normal distributed data were presented as Mean \pm Standard Deviation (SD). Student's t-test was used to compare between groups. after six-month of intervention. Qualitative data were described as numbers and percentages and were analyzed using the Chi-Square test. Association between measured variables was performed using the Spearman's rank correlation coefficient. Receiver operating characteristic (ROC) curve was plotted, and the area under the ROC curve was calculated to describe the predictive accuracy of different markers. All analyses were initially performed on an intention-to-treat (ITT) basis. It was considered statistically significant when $p<0.05$.

\section{Results}

\subsection{Baseline Characteristics}


Enrollment and follow-up process of the participants are demonstrated in Figure 1. Out of 63 female patients who participated in this study, two patients in omega-3 group lost to follow up and only one patient follow in the control group lost to follow up. Accordingly, 60 patients were included in the final analysis; 20 patients in the control group and 40 patients in the omega-3 group.

Patient's baseline data and characteristics are summarized in Table 1. At baseline, non-significant differences were found between the omega- 3 and the control groups regarding the age (48.7 $\pm 11.2 \mathrm{vs}$ $49.3 \pm 12.2$ years, $p=0.85)$, BMI $\left(25.2 \pm 3.5 \mathrm{vs} 26.3 \pm 3.5 \mathrm{Kg} / \mathrm{m}^{2}, \mathrm{p}=0.25\right)$, duration of dialysis $(9.9 \pm 6.6 \mathrm{vs}$ $9.4 \pm 5.7$ years, $p=0.75)$ and the associated diseases $(p>0.05)$, respectively.

\subsection{Clinical Blood Biochemical Analyses}

Comparison between the omega-3 and the control groups at baseline and after six months of intervention and follow-up is shown in Table 2. Levels of fetuin-A and OPG were increased after six months of omega3 supplementation $(p<0.001)$ compared with baseline. On the other hand, levels of fetuin-A, and OPG were not significantly changed in the control group after six months compared with baseline. As shown in Table 2 and Figure 2 and compared to control group, Fetuin-A was increased after six months in the omega-3 group and was decreased in the control group $(p=0.005)$. OPG level increased in both studied group during the study period with more increase in the omega 3 group with statistically significant difference as compared to the control group $(p=0.015)$. Serum creatinine, BUN, phosphorus, hemoglobin and PTH levels were not significantly changed in the omega-3 or the control groups after six months compared with baseline ( $p>0.05)$. TG Serum levels were significantly decreased in both groups at the end of the study period compared with baseline. The mean differences in the serum TG levels were not statistically significant between both groups.

Serum albumin levels were increased in the omega-3 group and decreased in the control group at the end of the study period. However, a non-significant difference was observed comparing both groups after six months of intervention $(p=0.360)$ (Table 2). At the end of this study, the mean serum Ca levels were significantly decreased in the omega-3 group $(p=0.046)$, whereas there was a non significant reduction in the control group $(p=0.16)$, when compared with baseline level (Table 2$)$. The decrease in serum Ca levels in the omeg-3 group was not statistically significant compared with the control group $(p=0.26)$.

Omega-3 intake was tolerated during the study and no patients reported any serious side effect. Two out of $40(5 \%)$ patients complained about the large capsule size that make it hard to swallowed. However, patients were advised to take their Omega 3 supplements with a large cup of water. Only five out of 40 patients $(8 \%)$ reported that they had mild gastrointestinal tract (GIT) symptoms such as nausea and diarrhea which are slightly decreased when taken with food. Furthermore, three patients reported fishy smells and anorexia with omega-3 supplementation, as shown in Table 3.

Figure 3 shows the Spearman's correlation analysis, a significant positive correlation was observed between fetuin-A and OPG levels $\left(r=0.457, p<0.001^{\star *}\right)$ after six months of omega-3 intake. 
Figure 4 shows the ROC curve for fetuin-A and OPG levels after six months of omega-3 supplementation. The AUC values associated with these ROC curves were 0.725 ( $P=0.005 ; 95 \% \mathrm{Cl} 0.586-0.864)$, and 0.693 $(P=0.015 ; 95 \% \mathrm{Cl} 0.554-0.832)$ for fetuin-A and OPG, respectively.

\section{Discussion}

In the presented study, we enrolled $60 \mathrm{HD}$ patients to study the effect of omega-3 supplementation after six months on the vascular calcification biomarkers fetuin-A and OPG. Serum levels of fetuin A and OPG were significantly increased after six months of omega-3 supplementation compared with baseline in the studied hemodialysis patients. These finding are in consistence with a previous study, conducted on 47 patients on dialysis, which concluded that increased fetuin-A levels after omega-3 FA supplementation for six months may work positively for dialysis patients in the aspects of nutrition, mortality, and VC [26].

The cardioprotective role of omega-3 in HD patients is owing to the decrease in the carotid intimamedia thickness (CIMT) hindering the progression of atherosclerosis [27] or through the modulation of vascular calcification biomarkers such as fetuin-A [26] and the RANKL/RANK/OPG system in mice with metabolic syndrome [28]. In patients undergoing long-term HD, the VC process was found to be a very common adverse eventthat finally leads to CVD [29]. The leading cause of death in HD patients is atherogenesis which is interconnected with both VC and inflammation [30]. Fetuin-A glycoprotein is a calcium regulator that inhibits the precipitation of calcium phosphate and plays an important role in both calcification and inflammation processes [31]. Fetuin-A serum levels during acute inflammation are rapidly downregulated [32]. A previous cross-sectional study enrolled 312 hemodialysis patients demonstrated that fetuin-A serum levels were significantly lower in hemodialysis patients than in healthy controls. In addition, fetuin-A deficiency is associated with inflammation and links vascular calcification to mortality in patients on dialysis [8]. In consonance with our results, Ozyazgan et al., found that levels of fetuin-A were increased after omega-3 intake for two months in diabetic patients [33]. Other researchers found that levels of fetuin-A are positively associated with metabolic syndrome (MetS), the accumulation of visceral adipose tissue (VAT) and the insulin resistance in the normal healthy population [34; 35].

It was proved that fetuin-A inhibits in vitro vesicle-mediated VSMC that plays a beneficial role in CRF patients [36]. Furthermore, levels of fetuin-A are inversely related to valvular calcification in peritoneal dialysis patients [37]. In the early stages of calcification high levels of fetuin-A were found in children undergoing HD. This may be explained by its protective role against prolonged calcification and inflammatory environment [38]. The present study found a positive correlation between fetuin-A and OPG, this finding is in consistence with Koluman et al., study [39] who found that both biomarkers increased in diabetic patients. Additionally, this study found that the levels of OPG were significantly increased in patients after being supplemented with omega-3 compared with the control group. Consistently Kolahi et al., [40] illustrated that the levels of OPG were significantly increased in female patients suffering from rheumatoid arthritis after being supplemented with one gram fish oil per day for three months. Similarly, 
the OPG level was increased in hyperlipidemic patients who received 0.5 liter of fortified milk with fish oil, oleic acid, and vitamins per day for one year [41]. On the contrary, Zakaria et al., [42] found that serum OPG levels showed non-significant changes following the daily administration of the combined supplementation of fish oil with antioxidants such as wheat germ oil (WGO) for four months. Another study, conducted on 127 postmenopausal women with moderate cardiovascular risk, showed a decrease in total cholesterol, however, the levels of OPG were not changed after 12 months of consuming 40 $\mathrm{mg} / 100 \mathrm{~mL}$ of EPA and DHA [43]. Our results from the ROC curves showed that fetuin-A levels followed by OPG levels could be used as predictor biomarkers in HD patients for VC progression and development after six months of omega-3 intake. In general, OPG is known to be a prognostic marker of mortality in ESRD because it plays a major role in the VC process [44]. Another study suggested that the measurement of OPG levels should be added to the routine biological follow up for HD patients. Results from another study, that followed up prospectively $185 \mathrm{HD}$ patients for two yearsillustrated that the elevation of OPG level can be used as strong predictor of mortality in HD patients. this suggests that OPG is a vascular risk factor, particularly, in patients who have high C-reactive protein levels [45].

The presented study showed that omega-3 supplementation for six months did not affect the levels of serum creatinine, BUN, phosphorus, PTH and hemoglobin. Consistently the levels of PTH, phosphorus, and hemoglobin were not changed in $23 \mathrm{HD}$ patients after receiving $3000 \mathrm{mg}$ of Fish oil (omega-3 fatty acids withwheat germ oil) for four months [42]. Similarly, after ingestion of $1800 \mathrm{mg}$ of omega 3 fatty acids for four months, the levels of PTH were not significantly changed [46]. Furthermore, Vernaglione et al., [47] did not find a significant difference in hemoglobin after 12 months of omega-3 (2gram/daily) intake in HD patients. As opposed to our results, a study that used 2.4 gram per day for seven weeks in HD patients, revealed a slight increase in hemoglobin levels [18].

In our study calcium levels were significantly decreased in the omega-3 group, whereas there was a nonsignificant reduction in the control group. On the other hand, another a pervious study showed a slight increase in calcium levels after omega-3 supplementation for 12 weeks in peritoneal dialysis patients [48], and for four months HD patients [42]. The present study revealed that albumin levels were slightly increased after omega-3 supplementation compared with the control group. In agreement with our study, an earlier study conducted on HD patients, showed that albumin levels were slightly increased in patients who completed their omega-3 with protein supplementation regimen for six months [49]. Our study found that serum triglycerides levels were significantly decreased in the Omega 3 group and the control group as compared to the baseline, with no significant difference between both groups after six months of intervention. This may be attributed to the use of heparin in HD therapy, various therapy-related factors (such as statin, niacin and fibrate) which are thought to cause modifications in triglyceride and triglyceride-rich lipoproteins [50]. Some investigators have reported that dialysis using synthetic membranes with high-flux characteristics resulted in a reduction of triglyceride rich lipoproteins and an increase in HDL cholesterol and apoA1 levels [51].

This finding comes in agreement with another study that found a significant reduction in serum triglycerides compared with baseline after ten weeks of omega-3 intake in HD patients [52]. Omega-3 is a 
well-known hypotriglyceridemic agent because it works by inhibiting the fatty acid synthesis in the liver and hence it inhibits the synthesis of triglycerides [53; 54].

\section{Conclusion}

Our findings showed a beneficial effect of omega-3 supplementation in female patients with chronic renal failure who are undergoing hemodialysis because it increases the potent vascular calcification inhibitors Fetuin-A and Osteoprotegerin levels. Thus omega-3 can be used as a cardiovascular protective supplementation, and it may decrease cardiovascular events in CKD patients. However, a largescale, welldesigned, prospective clinical trials are still needed to precisely determine the impact of omega-3 supplementation in HD patients.

\section{Study limitations}

The major limitation in this study was the quite small sample size, the short follow up duration and the open-label, controlled study without placebo. Therefore, to understand the efficacy of omega- 3 on the vascular calcification biomarkers, further double-blind studies should be made on large scale and for longer duration to confirm our research findings.

\section{Declarations}

\section{Acknowledgments}

We are thankful to our participants and the medical staff in the Renal Dialysis Unit at Al Mouwasat University Hospital for their honest assistance and recommendations.

\section{Declaration of Competing Interest}

The authors declare that there is no conflict of interest.

\section{Funding}

This study has not received any type of grant or any fund from commercial, public, or nonprofit groups.

\section{References}

1. Fox CS, Matsushita K, Woodward M, et.al. Associations of kidney disease measures with mortality and end-stage renal disease in individuals with and without diabetes: a meta-analysis. Chronic Kidney Disease Prognosis Consortium.Lancet. 2012 ; 10;380 (9854):1662-73. doi: 10.1016/S01406736(12)61350-6.

2. Raggi $P$, Boulay $A$, Chasan-Taber $S$, et al. Cardiac calcification in adult hemodialysis patients. A link between end-stage renal disease and cardiovascular disease? J Am Coll Cardiol. 2002; 20;39(4):695701. doi: 10.1016/s0735-1097(01)01781-8. 
3. Mizobuchi M, Towler D, Slatopolsky E. Vascular calcification:

the killer of patients with chronic kidney disease. J Am Soc Nephrol. 2009 ;20(7):1453-64. doi: 10.1681/ASN.2008070692.

4. Block GA, Klassen PS, Lazarus JM, et.al. Mineral metabolism, mortality, and morbidity in maintenance hemodialysis. J Am Soc Nephrol. 2004; 15(8):2208-18. doi: 10.1097/01.ASN.0000133041.27682.A2.

5. Derici U, El Nahas AM. Vascular calcifications in uremia: old concepts and new insights. Semin Dial 2006;19(1):60-8. doi: 10.1111/j.1525-139X.2006.00120.x.

6. Jahnen-Dechent W, Heiss A, Schäfer C, Ketteler M.

Fetuin-A regulation of calcified matrix metabolism. Circ Res. $2011 ; 10 ; 108(12): 1494-509$. doi: 10.1161/CIRCRESAHA.110.234260.

7. Schafer $C$, Heiss A, Schwarz A, et al. The serum protein alpha 2-HeremansSchmid glycoprotein/fetuin-A is a systemically acting inhibitor of ectopic calcification. $J$ Clin Invest. 2003;112(3):357-66. doi: 10.1172/JCl17202.

8. Ketteler M, Wanner C, Metzger T, et al. Deficiencies of calcium-regulatory proteins in dialysis patients: a novel concept of cardiovascular calcification in uremia. Kidney Int Suppl. 2003a;(84):S84-7. doi: 10.1046/j.1523-1755.63.s84.21.x.

9. Ketteler M, Bongartz P, Westenfeld R, et al. Association of low fetuin-A (AHSG) concentrations in serum with cardiovascular mortality in patients on dialysis: a cross-sectional study. J.Lancet. 2003b; 8;361(9360):827-33. doi: 10.1016/S0140-6736(03)12710-9.

10. Collin-Osdoby P, Rothe L, Anderson F, et. al. Receptor activator of NF-kappa B and osteoprotegerin expression by human microvascular endothelial cells, regulation by inflammatory cytokines, and role in human osteoclastogenesis. J Biol Chem. 2001; 8;276(23):20659-72. doi:

10.1074/jbc.M010153200.

11. Nybo M, Rasmussen LM. Osteoprotegerin released from the vascular wall by heparin mainly derives from vascular smooth muscle cells. Atherosclerosis. 2008a;201(1):33-5. doi:

10.1016/j.atherosclerosis.2008.03.026.

12. Nybo M, Rasmussen LM. The capability of plasma osteoprotegerin as a predictor of cardiovascular disease: A systematic literature review. Eur J Endocrinol. 2008b;159(5):603-8. doi: 10.1530/EJE-080554.

13. Sandberg WJ, Yndestad A, Øie E, et. al. Enhanced T-cell expression of RANK ligand in acute coronary syndrome: possible role in plaque destabilization. Arterioscler Thromb Vasc Biol. 2006 Apr;26(4):85763. doi: 10.1161/01.ATV.0000204334.48195.6a.

14. Davidson $\mathrm{MH}$, Stein EA, Bays HE, et. al. COMBination of prescription Omega-3 with Simvastatin (COMBOS) Investigators. Efficacy and tolerability of adding prescription omega-3 fatty acids $4 \mathrm{~g} / \mathrm{d}$ to simvastatin $40 \mathrm{mg} / \mathrm{d}$ in hypertriglyceridemic patients: an 8-week, randomized, double-blind, placebocontrolled study. Clin Ther. 2007 Jul;29(7):1354-67. doi: 10.1016/j.clinthera.2007.07.018. 
15. Eraky SM, Ramadan NM. Effects of omega-3 fatty acids and metformin combination on diabetic cardiomyopathy in rats through autophagic pathway: Effects of omega-3 fatty acids and metformin combination on diabetic cardiomyopathy: Role of autophagy. J Nutr Biochem. 2021 Jun 5:108798. doi: 10.1016/j.jnutbio.2021.108798.

16. Pisaniello AD, Psaltis PJ, King PM, et. al. Omega-3 fatty acids ameliorate vascular inflammation: A rationale for their atheroprotective effects. Atherosclerosis. 2021; 324: 27-37. doi: 10.1016/j.atherosclerosis.2021.03.003.

17. Djoussé L, Akinkuolie AO, Wu JH, et. al. Fish consumption, omega-3 fatty acids and risk of heart failure: a meta-analysis. Clin Nutr. 2012;31(6):846-53. doi: 10.1016/j.clnu.2012.05.010.

18. Perunicic-Pekovic GB, Rasic ZR, Pljesa SI, et al. Effect of n-3 fatty acids on nutritional status and inflammatory markers in haemodialysis patients. Nephrology (Carlton). 2007;12(4):331-6. doi: 10.1111/j.1440-1797.2007.00777.x.

19. Endo J, Arita M. Cardioprotective mechanism of omega-3 polyunsaturated fatty acids. J Cardiol. 2016;67(1):22-7. doi: 10.1016/j.jjcc.2015.08.002.

20. Foroughinia F, Rohani Rad E. Impact of Supplementation with Omega-3 in the Prevention of ContrastInduced Nephropathy Following Elective Percutaneous Coronary Intervention in Patients with Chronic Kidney Disease: A Randomized Placebo-Controlled Trial. Int J Prev Med. 2020 Dec 11;11:193. doi: 10.4103/ijpvm.IJPVM_460_18. eCollection 2020.

21. Lee $\mathrm{CH}, \mathrm{Fu}$ Y, Yang SJ, et. al. Effects of Omega-3 Polyunsaturated Fatty Acid Supplementation on Non-Alcoholic Fatty Liver: A Systematic Review and Meta-Analysis. Nutrients. 2020; 12(9):2769. doi: 10.3390/nu12092769.

22. Patan MJ, Kennedy DO, Husberg C, et. al. Supplementation with oil rich in eicosapentaenoic acid, but not in docosahexaenoic acid, improves global cognitive function in healthy, young adults: results from randomized controlled trials. Am J Clin Nutr. 2021 Jun 10:nqab174. doi: 10.1093/ajcn/nqab174.

23. Farrington K, Warwick G. Renal Association Clinical Practice Guideline on Planning, Initiating and Withdrawal of Renal Replacement Therapy. Nephron Clin Pract. 2011;118(Suppl 1):c189-208. doi: $10.1159 / 000328069$.

24. Sangeda RZ, Mosha F, Prosperi M, et. al. Pharmacy refill adherence outperforms self-reported methods in predicting HIV therapy outcome in resource-limited settings. BMC public health 2014; 14:1035. doi: 10.1186/1471-2458-14-1035.

25. Keys A, Fidanza F, Karvonen MJ, et. al. Indices of relative weight and obesity. Int J Epidemiol. 2014; 43(3):655-65. doi: 10.1093/ije/dyu058.

26. An WS, Lee SM, Son YK, et al. Omega-3 fatty acid supplementation increases 1,25dihydroxyvitamin D and fetuin-A levels in dialysis patients.Nutr Res. 2012; 32(7):495-502. doi: 10.1016/j.nutres.2012.06.005.

27. Kajbaf MH, Khorvash F, Mortazavi M, et al. Does Omega-3 supplementation decrease carotid intimamedia thickening in hemodialysis patients? J Res Pharm Pract. 2016-Dec;5(4):252-256. doi: 
10.4103/2279-042X.192451.

28. Naranjo MC, Bermudez B, Garcia I, et al. Dietary fatty acids on aortic root calcification in mice with metabolic syndrome. Food Funct. 2017; 19;8(4):1468-1474. doi: 10.1039/c7fo00143f.

29. Floege J, Ketteler M. Vascular calcification in patients with end-stage renal disease. Nephrol Dial Transplant. 2004;19 Suppl 5:V59-66. doi: 10.1093/ndt/gfh1058.

30. Stenvinkel P, Wang K, Qureshi AR, et al. Low fetuin-A levels are associated with cardiovascular death: Impact of variations in the gene encoding fetuin. Kidney Int. 2005; 67(6):2383-92. doi: 10.1111/j.1523-1755.2005.00345.x.

31. Ciaccio M, Bivona G, Di Sciacca R, et al. Changes in serum fetuin-Aand inflammatory markers levels in end-stage renal disease (ESRD): effect of a single session haemodialysis. Clin Chem Lab Med. 2008;46(2):212-4. doi: 10.1515/CCLM.2008.041.

32. Gangneux C, Daveau M, Hiron $M$, et. al. The inflammation-induced down-regulation of plasma FetuinA (alpha2HS-Glycoprotein) in liver results from the loss of interaction between long C/EBP isoforms at two neighbouring binding sites. Nucleic Acids Res. 2003; 15;31(20):5957-70. doi: $10.1093 / \mathrm{nar} / \mathrm{gkg} 788$.

33. Ozyazgan S, Karaoglu K, Kurt A, et al. Effects of omega-3 polyunsaturated fatty acid supplementation on serum fetuin-A levels in type 2 diabetic patients. Minerva Med. 2013; 104(3):28793.

34. Ix JH, Wassel CL, Chertow GM, et al. Health Aging and Body Composition Study. Fetuin-A and change in body composition in older persons. J Clin Endocrinol Metab. 2009; 94(11):4492-8. doi: 10.1210/jc.2009-0916.

35. Ix JH, Shlipak MG, Brandenburg VM, et. al. Association between human fetuin-A and the metabolic syndrome: data from the Heart and Soul Study. Circulation. 2006; 113(14):1760-7. doi: 10.1161/CIRCULATIONAHA.105.588723.

36. Reynolds JL, Skepper JN, McNair R, et al. Multifunctional roles for serum protein fetuin-a in inhibition of human vascular smooth muscle cell calcification. J Am Soc Nephrol. 2005; 16(10):2920-30. doi: 10.1681/ASN.2004100895.

37. Wang AY, Woo J, Lam CW, et al. Associations of serum fetuin-A with malnutrition, inflammation, atherosclerosis and valvular calcification syndrome and outcome in peritoneal dialysis patients. Nephrol Dial Transplant. 2005; 20(8):1676-85. doi: 10.1093/ndt/gfh891.

38. Shroff RC, Shah V, Hiorns MP, et. al.

The circulating calcification inhibitors, fetuin-A and osteoprotegerin, but not matrix Gla protein, are associated with vascular stiffness and calcification in children on dialysis. Nephrol Dial Transplant. 2008; 23(10):3263-71. doi: 10.1093/ndt/gfn226.

39. Koluman BU, Mutluay R, Derici UB, et. al. Association between osteoprotegerin, fetuinA, carotid intima media thickness, and urinary albumin excretion in Type 2 diabetes. Clin Nephrol. 2013; 80(1):9-16. doi: 10.5414/CN107920. 
40. Kolahi S, Ghorbanihaghjo A, Alizadeh S, et. al. Fish oil supplementation decreases serum soluble receptor activator of nuclear factor-kappa $B$ ligand/osteoprotegerin ratio in female patients with rheumatoid arthritis. Clin Biochem. 2010; 43(6):576-80. doi: 10.1016/j.clinbiochem.2009.12.011.

41. Martin-Bautista E, Muñoz-Torres M, Fonolla J, et. al. Improvement of bone formation biomarkers after 1-year consumption with milk fortified with eicosapentaenoic acid, docosahexaenoic acid, oleic acid, and selected vitamins. Nutr Res. 2010; 30(5):320-6. doi: 10.1016/j.nutres.2010.05.007.

42. Zakaria H, Mostafa TM, El-Azab GA, et. al. The impact of fish oil and wheat germ oil combination on mineral-bone and inflammatory markers in maintenance hemodialysis patients: a randomized, double-blind, placebo-controlled clinical trial. Int Urol Nephrol. 2017; 49(10):1851-1858. doi: 10.1007/s11255-017-1643-6.

43. Fonolla-Joya J, Reyes-García R, García-Martín A, et. al. Daily Intake of Milk Enriched with n-3 Fatty Acids, Oleic Acid, and Calcium Improves Metabolic and Bone Biomarkers in Postmenopausal Women. J Am Coll Nutr. 2016;35(6):529-536. doi: 10.1080/07315724.2014.1003114.

44. Winther S, Christensen JH, Flyvbjerg A, et. al. Osteoprotegerin and mortality in hemodialysis patients with cardiovascular disease. CLIN Nephrol. 2013;80(3):161-7. doi: 10.5414/CN107803.

45. Morena $\mathrm{M}$, Terrier $\mathrm{N}$, Jaussent $\mathrm{I}$, et al. Plasma osteoprotegerin is associated with mortality in hemodialysis patients. J Am Soc Nephrol. 2006;17(1):262-70. doi: 10.1681/ASN.2005030260.

46. Gharekhani A, Khatami MR, Dashti-Khavidaki S, et al. Potential effects of omega3 fatty acids on anemia and inflammatory markers in maintenance hemodialysis patients. Daru. 2014; 22(1):11. doi: 10.1186/2008-2231-22-11.

47. Vernaglione L, Cristofano $C$, Chimienti S. Omega-3 polyunsaturated fatty acids and proxies of cardiovascular disease in hemodialysis: a prospective cohort study. J Nephrol. 2008; 21(1):99-105.

48. An WS, Lee SM, Son YK, et al. Effect of omega-3 fatty acids on the modification of erythrocyte membrane fatty acid content including oleic acid in peritoneal dialysis patients. Prostaglandins Leukot Essent Fatty Acids. 2012; 86(1-2):29-34. doi: 10.1016/j.plefa.2011.10.009.

49. Daud ZA, Tubie B, Adams J, et al. Effects of protein and omega-3 supplementation, provided during regular dialysis sessions, on nutritional and inflammatory indices in hemodialysis patients. Vasc Health Risk Manag. 2012; 8:187-95. doi: 10.2147/VHRM.S28739.

50. Wanner, C., Bahner, U., Mattern, R., et. al. Effect of dialysis flux and membrane material on dyslipidaemia and inflammation in haemodialysis patients. Nephrol Dial Transplant. 2004; 19, 2570 5.

51. De Précigout V, Higueret D, Larroumet N, et al: Improvement in lipid profiles and triglyceride removal in patients on polyamide membrane hemodialysis. Blood Purif 1996;14(2):170-6. doi: 10.1159/000170259.

52. Kooshki A, Taleban FA, Tabibi H, et. al. Effects of omega-3 fatty acids on serum lipids, lipoprotein (a), and hematologic factors in hemodialysis patients. Ren Fail. 2011;33(9):892-8. doi: 
10.3109/0886022X.2011.605536.

53. Shimano H, Yahagi N, Amemiya-Kudo M, et al. Sterol regulatory element-binding protein-1 as a key transcription factor for nutritional induction of lipogenic enzyme genes. J Biol Chem. 1999 Dec 10;274(50):35832-9. doi: 10.1074/jbc.274.50.35832.

54. Jump DB, Botolin D, Wang Y, et. al. Fatty acid regulation of hepatic gene transcription. J Nutr. 2005; 135(11):2503-6. doi: 10.1093/jn/135.11.2503.

\section{Tables}

Table 1: Baseline Characteristics of Enrolled Patients in Both Groups 


\begin{tabular}{|c|c|c|c|}
\hline \multirow[t]{2}{*}{ Variable } & Omeg-3 group & Control group & $P$ value \\
\hline & $\mathrm{N}=40$ & \multicolumn{2}{|l|}{$N=20$} \\
\hline Age (years) & $48.70 \pm 11.16$ & $49.30 \pm 12.23$ & 0.850 \\
\hline Range & $(29-70)$ & \multicolumn{2}{|l|}{$(30-70)$} \\
\hline BMI (kg/m2) & $25.21 \pm 3.51$ & $26.34 \pm 3.54$ & 0.247 \\
\hline \multirow[t]{2}{*}{ Duration of dialysis (years) } & $9.91 \pm 6.56$ & $9.35 \pm 5.72$ & 0.745 \\
\hline & $(1.5-26)$ & \multicolumn{2}{|l|}{$(2-22)$} \\
\hline \multicolumn{4}{|l|}{ Associated diseases, n (\%) } \\
\hline Hepatitis C & $6(15)$ & $3(15)$ & 1.000 \\
\hline Diabetes & $12(30)$ & $5(25)$ & 0.685 \\
\hline Hyperparathyrdosim & $3(7.5)$ & $1(5)$ & 0.714 \\
\hline Hypertension & $17(42.5)$ & $10(50)$ & 0.582 \\
\hline Hypotension & $6(15)$ & $4(20)$ & 0.624 \\
\hline \multicolumn{4}{|l|}{ Co-administered medications, n (\%) } \\
\hline human insulin injection & $6(15)$ & $2(10)$ & 0.591 \\
\hline ACEls & $7(17.5)$ & $5(25)$ & 0.494 \\
\hline ARBs & $9(22.5)$ & $2(10)$ & 0.238 \\
\hline angiotensin-II receptor (type AT1) antagonist & $3(7.5)$ & $2(10)$ & 0.741 \\
\hline Calcimimetics & $6(15)$ & $3(15)$ & 1.000 \\
\hline Erythropoietin & $10(25)$ & $5(25)$ & 1.000 \\
\hline ribaviriv ${ }^{\circledR}$ plus Interferon & $2(5)$ & $1(5)$ & 1.000 \\
\hline Alpha adrenergic agonist & $6(15)$ & $4(20)$ & 0.624 \\
\hline Niacin & $3(7.5)$ & $2(10)$ & 0.741 \\
\hline Fibrates & $9(22.5)$ & $4(20)$ & 0.825 \\
\hline Statins & 7 (17.5) & $6(30)$ & 0.268 \\
\hline
\end{tabular}

values are presented as mean \pm SD or number (percentage). $p$ values for each group derived from unpaired $t$ test or ${ }^{*}$ Chi squared test as appropriate. $P<0.05$ is considered significant.

Table 2: Comparison between omega-3 and control Groups at baseline and after six months of intervention and follow-up. 


\begin{tabular}{|c|c|c|c|c|c|c|c|c|}
\hline \multirow[t]{2}{*}{ Variable } & \multirow[b]{2}{*}{ Baseline } & \multicolumn{2}{|c|}{ Omega-3 group } & \multirow{2}{*}{$\begin{array}{l}\neq P \\
\text { value }\end{array}$} & \multicolumn{3}{|c|}{ Control group } & \multirow{2}{*}{$\begin{array}{l}\dagger P \\
\text { value }\end{array}$} \\
\hline & & $\begin{array}{l}\text { After } 6 \\
\text { months }\end{array}$ & $\begin{array}{l}\text { * } P \\
\text { value }\end{array}$ & & Baseline & $\begin{array}{l}\text { After } 6 \\
\text { months }\end{array}$ & $\begin{array}{l}* P \\
\text { value }\end{array}$ & \\
\hline $\begin{array}{l}\text { Triglycerides } \\
(\mathrm{mg} / \mathrm{dL})\end{array}$ & $\begin{array}{l}165.98 \pm \\
34.25\end{array}$ & $\begin{array}{l}161.94 \pm \\
33.66\end{array}$ & $<0.001$ & 0.676 & $\begin{array}{l}163.11 \pm \\
29.39\end{array}$ & $\begin{array}{l}155.76 \pm \\
24.33\end{array}$ & 0.004 & 0.447 \\
\hline $\begin{array}{l}\text { Albumin } \\
\text { (g/ dL) }\end{array}$ & $\begin{array}{l}3.51 \pm \\
0.51\end{array}$ & $\begin{array}{l}3.59 \pm \\
0.52\end{array}$ & 0.041 & 0.631 & $\begin{array}{l}3.36 \\
\pm 0.40\end{array}$ & $\begin{array}{l}3.27 \pm \\
0.43\end{array}$ & 0.257 & 0.360 \\
\hline $\begin{array}{l}\mathrm{SCr} \\
(\mathrm{mg} / \mathrm{dL})\end{array}$ & $\begin{array}{l}10.05 \pm \\
1.34\end{array}$ & $\begin{array}{l}10.47 \pm \\
1.75\end{array}$ & 0.052 & 0.423 & $\begin{array}{l}10.38 \pm \\
1.79\end{array}$ & $\begin{array}{l}10.91 \pm \\
1.68\end{array}$ & 0.965 & 0.354 \\
\hline $\begin{array}{l}\text { BUN } \\
(\mathrm{mg} / \mathrm{dL})\end{array}$ & $\begin{array}{l}155.53 \pm \\
26.05\end{array}$ & $\begin{array}{l}148.48 \pm \\
28.69\end{array}$ & 0.115 & 0.106 & $\begin{array}{l}165.65 \pm \\
12.36\end{array}$ & $\begin{array}{l}158.0 \pm \\
22.37\end{array}$ & 0.118 & 0.199 \\
\hline $\begin{array}{l}\text { Phosphorus } \\
\text { (mg/dL) }\end{array}$ & $\begin{array}{l}6.10 \pm \\
1.57\end{array}$ & $\begin{array}{l}6.04 \pm \\
1.47\end{array}$ & 0.856 & 0.175 & $\begin{array}{l}6.75 \pm \\
1.98\end{array}$ & $\begin{array}{l}6.83 \pm \\
1.15\end{array}$ & 0.860 & 0.041 \\
\hline $\begin{array}{l}\text { Calcium } \\
(\mathrm{mg} / \mathrm{dL})\end{array}$ & $\begin{array}{l}9.25 \\
\pm 1.77\end{array}$ & $\begin{array}{l}8.58 \pm \\
1.13\end{array}$ & 0.046 & 0.165 & $\begin{array}{l}8.63 \\
\pm 1.24\end{array}$ & $\begin{array}{l}8.25 \pm \\
0.89\end{array}$ & 0.159 & 0.262 \\
\hline $\begin{array}{l}\text { Hemoglobin } \\
(\mathrm{g} / \mathrm{dL})\end{array}$ & $\begin{array}{l}10.96 \\
\pm 1.88\end{array}$ & $\begin{array}{l}11.34 \pm \\
2.36\end{array}$ & 0.228 & 0.989 & $\begin{array}{l}10.95 \pm \\
1.42\end{array}$ & $\begin{array}{l}11.03 \pm \\
1.86\end{array}$ & 0.867 & 0.608 \\
\hline $\begin{array}{l}\text { PTH } \\
\text { (pg/mL) } \\
\text { Median } \\
\text { Range }\end{array}$ & $\begin{array}{l}104.35 \\
(53.20- \\
1205.00)\end{array}$ & $\begin{array}{l}101.95 \\
(53.00- \\
1311)\end{array}$ & 0.276 & 0.748 & $\begin{array}{l}101.14 \\
(52,85- \\
261.65)\end{array}$ & $\begin{array}{l}99.78 \\
(53.10- \\
257.20)\end{array}$ & 0.490 & 0.754 \\
\hline $\begin{array}{l}\text { Fetuin-A } \\
(\mathrm{mg} / \mathrm{L}) \\
\text { Median } \\
\text { Range }\end{array}$ & $\begin{array}{l}439.25 \\
(48.90- \\
2233.20)\end{array}$ & $\begin{array}{l}860.15 \\
(154.60- \\
2186.70)\end{array}$ & $<0.001$ & 0.814 & $\begin{array}{l}397.55 \\
(52.70- \\
2063.90)\end{array}$ & $\begin{array}{l}339.25 \\
(56.40- \\
1753.60)\end{array}$ & 0.263 & 0.005 \\
\hline $\begin{array}{l}\text { OPG }(\mathrm{ng} / \mathrm{L}) \\
\text { Median } \\
\text { Range }\end{array}$ & $\begin{array}{l}63.60 \\
(33.50- \\
508.40)\end{array}$ & $\begin{array}{l}155.65 \\
(41.80- \\
758.60)\end{array}$ & $<0.001$ & 0.316 & $\begin{array}{l}70.20 \\
(31.00- \\
478.10)\end{array}$ & $\begin{array}{l}100.35 \\
(36.60- \\
324.50)\end{array}$ & 0.601 & 0.015 \\
\hline
\end{tabular}

Values are presented as mean \pm SD or median (range).

PTH parathyroid hormone, S.Cr: Serum creatinine, BUN blood urea nitrogen, OPG osteoprotegerin 
$\mathrm{p}$ values for each group derived from t test Wilcoxon Signed Ranks Test or Mann-Whitney Test as appropriate.

$\ddagger \mathrm{P}<0.05$ unpaired $t$ test (Omeg-3 group are significantly different from the control group before intervention).

Q $P<0.05$ Paired $t$ test (are significantly different from baseline).

† $\mathrm{P}<0.05$ unpaired $\mathrm{t}$ test (Omeg-3 group are significantly different from the control group after intervention).

Table 3: Adverse effects observed during the study.

\begin{tabular}{|llll|}
\hline Adverse effect & $\begin{array}{l}\text { Omega-3 group } \\
(\mathrm{n}=40)\end{array}$ & $\begin{array}{l}\text { Control group } \\
(\mathrm{n}=20)\end{array}$ & P-value \\
\hline Fishy smell and anorexia & $3(7.5)$ & $0(0)$ & 0.21 \\
\hline GIT symptoms & $5(8)$ & $0(0)$ & 0.02 \\
\hline
\end{tabular}

Values are presented as number (percentage).. $\mathrm{p}$ values for each group derived from. Chi squared test.

$P<0.05$ is considered significant. GIT: gastro-intestinal tract

\section{Figures}




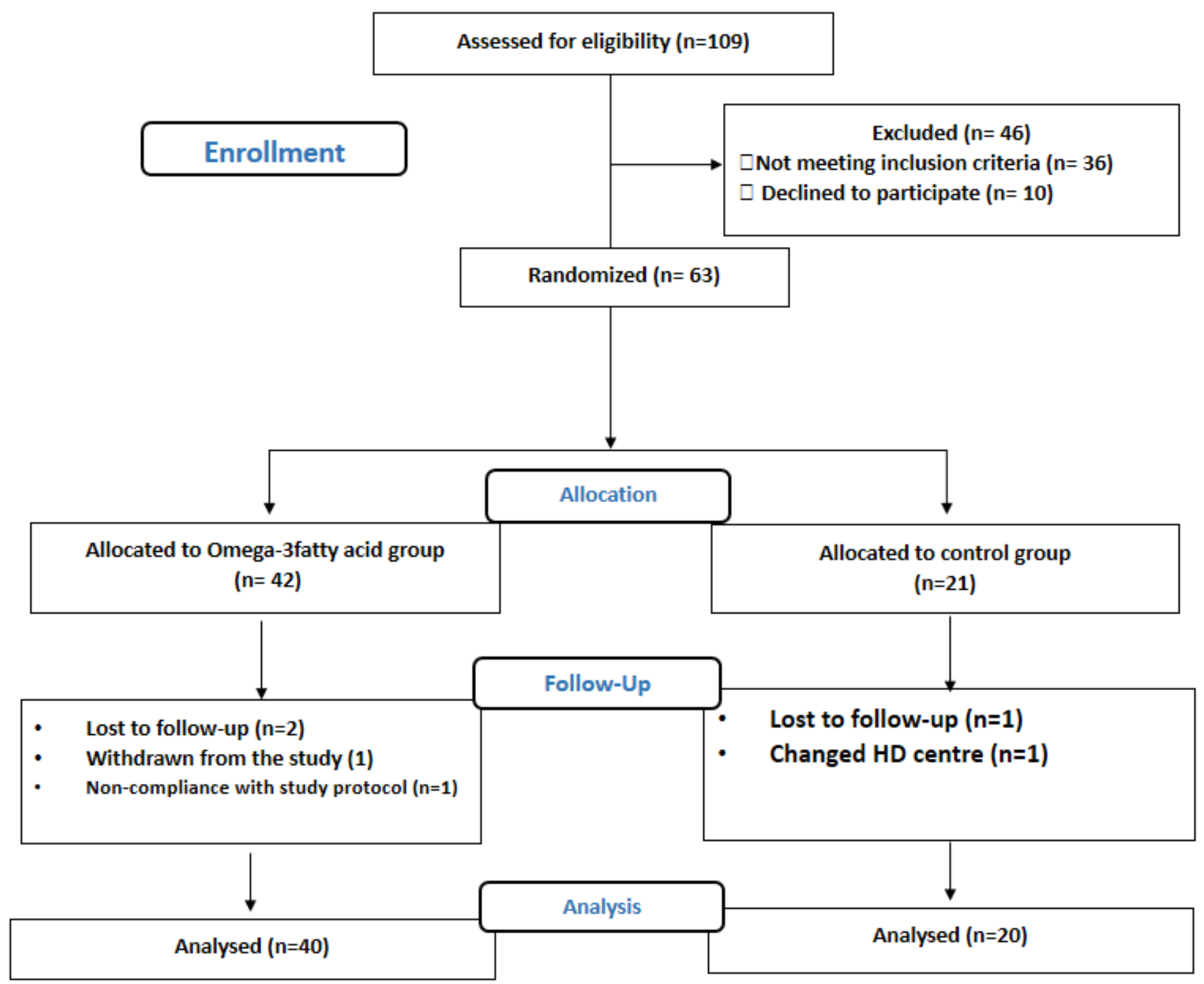

Figure 1

Flow Diagram of the progress through the parallel-randomized study. 

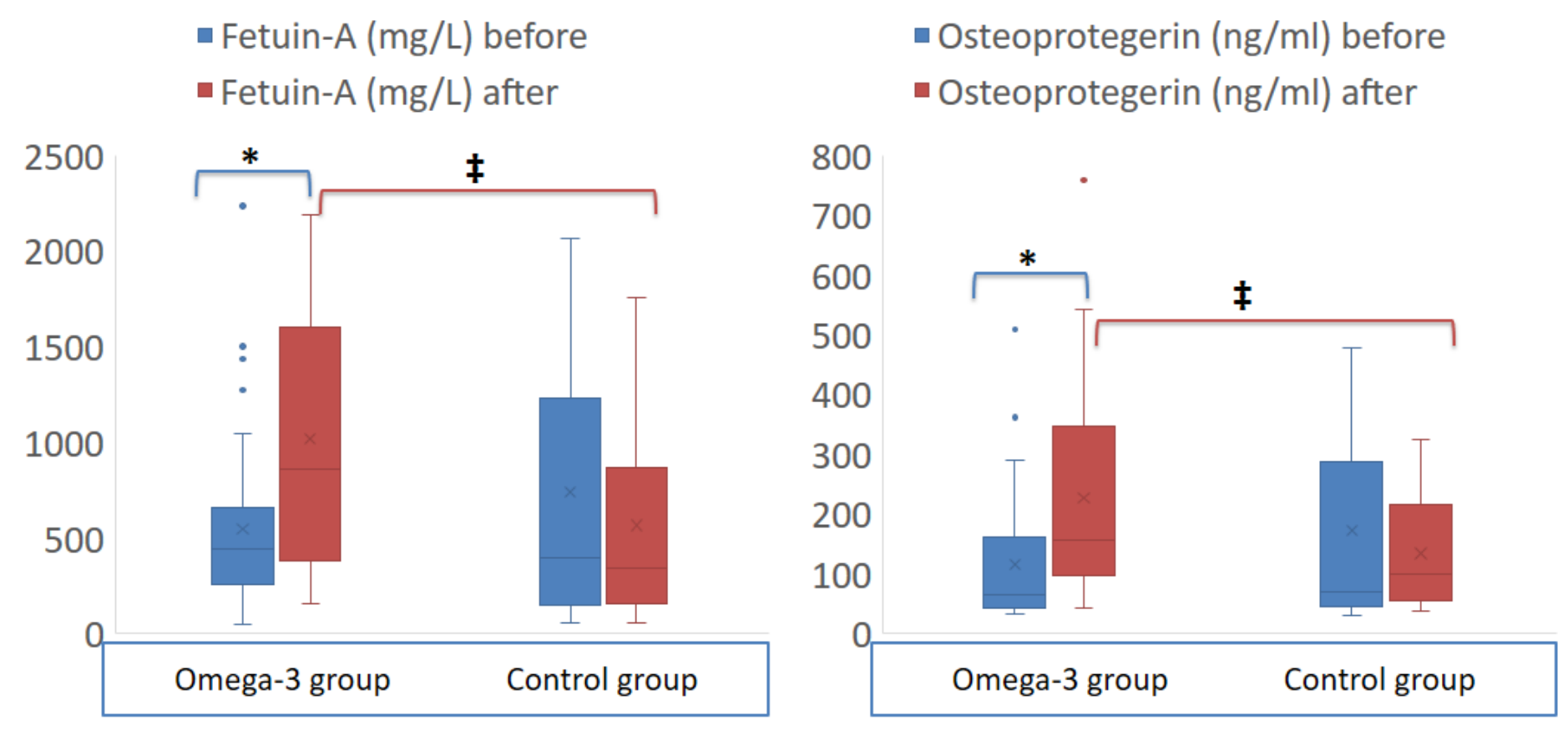

\section{Figure 2}

Change of Fetuin and OPG by omega-3 FA supplementation. ${ }^{*} \mathrm{P}<0.05$ (mean values are significantly different from baseline compared with after six months of intervention). $\mathrm{F}<0.001$ (omeg-3 group significantly different versus control group after 6 months of intervention) .

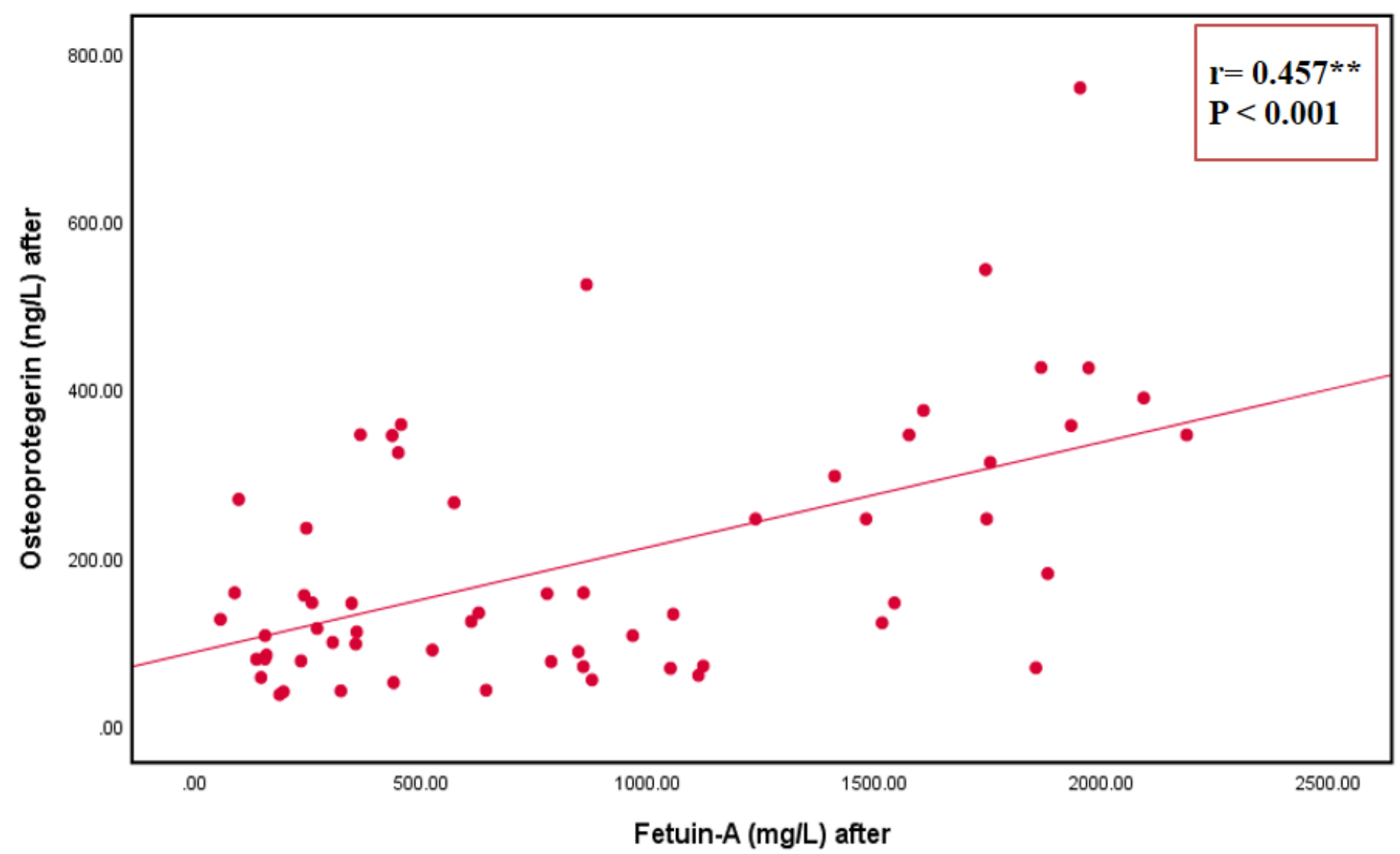

Page 18/19 
Figure 3

correlation between levels of fetuin-A and OPG levels after six months of omega-3 supplementation. $\mathrm{P}<$ 0.05 is considered significant.

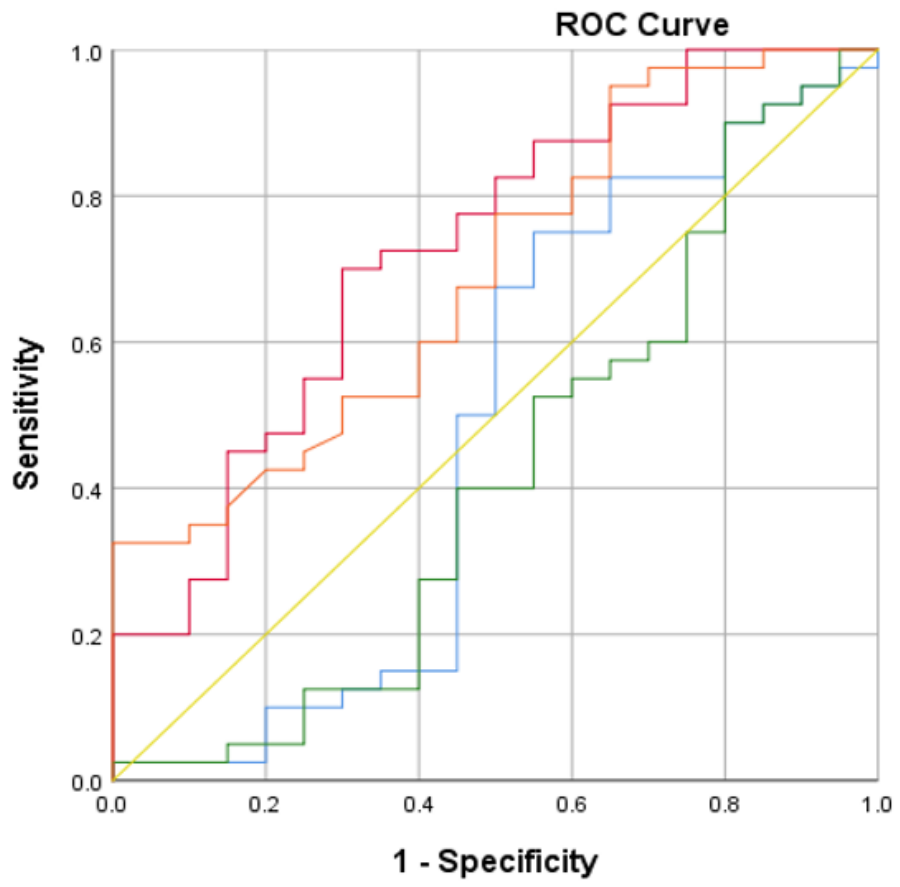

\author{
Source of the Curve \\ Fetuin-A ( $\mathrm{mg} / \mathrm{L})$ before \\ Fetuin-A (mg/L) after \\ - Osteoprotegerin $(\mathrm{ng} / \mathrm{ml})$ before \\ - Osteoprotegerin $(\mathrm{ng} / \mathrm{ml})$ after \\ - Reference Line
}

\begin{tabular}{|c|c|c|c|c|c|}
\hline \multicolumn{6}{|c|}{ Area Under the Curve } \\
\hline \multirow[b]{2}{*}{ Test Result Variable(s) } & \multirow[b]{2}{*}{ Area } & \multirow[b]{2}{*}{$\begin{array}{l}\text { Std. } \\
\text { Errora }^{a}\end{array}$} & \multirow[b]{2}{*}{$\begin{array}{l}\text { Asymptotic } \\
\text { Sig. }\end{array}$} & \multicolumn{2}{|c|}{$\begin{array}{l}\text { Asymptotic } 95 \% \\
\text { Confidence Interval }\end{array}$} \\
\hline & & & & $\begin{array}{l}\text { Lower } \\
\text { Bound }\end{array}$ & $\begin{array}{l}\text { Upper } \\
\text { Bound }\end{array}$ \\
\hline Fetuin-A (mg/L) before & 0.481 & 0.091 & 0.814 & 0.303 & 0.659 \\
\hline Fetuin-A (mg/L) after & 0.725 & 0.071 & 0.005 & 0.586 & 0.864 \\
\hline $\begin{array}{l}\text { Osteoprotegerin } \\
\text { (ng/L) before }\end{array}$ & 0.420 & 0.085 & 0.316 & 0.254 & 0.586 \\
\hline $\begin{array}{l}\text { Osteoprotegerin } \\
\text { (ng/L) after }\end{array}$ & 0.693 & 0.071 & 0.015 & 0.554 & 0.832 \\
\hline $\begin{array}{l}\text { The test result variable } \\
\text { the positive actual stat } \\
\text { biased. } \\
\text { a. Under the nonparam } \\
\text { b. Null hypothesis: true }\end{array}$ & $\begin{array}{l}\text { Osteop } \\
\text { oup an }\end{array}$ & tegerin ( & $\begin{array}{l}\text { ig/L) after has } \\
\text { ve actual state }\end{array}$ & $\begin{array}{l}\text { least one ti } \\
\text { roup. Statis }\end{array}$ & $\begin{array}{l}\text { between } \\
\text { s may be }\end{array}$ \\
\hline
\end{tabular}

\title{
Figure 4
}

Area under ROC curve of fetuin-A and OPG levels in the studied groups 